\title{
Tretinoin-based formulations - influence of concentration and vehicles on skin penetration
}

\author{
Edileia Bagatin ${ }^{1}$, Tais Aleriana Lucon Wagemaker ${ }^{2}$, Nelson dos Reis Aguiar \\ Júnior (in memoriam), Mirela Donato Gianeti ${ }^{2}$, Erika Maria Berardo Gonçalves ${ }^{3}$, \\ Patrícia Maria Berardo Gonçalves Maia Campos ${ }^{2, *}$
}

\author{
${ }^{1}$ Department of Dermatology, Federal University of São Paulo, UNIFESP, São Paulo, Brazil, ${ }^{2}$ Departament of Pharmaceutical \\ Sciences, Faculty of Pharmaceutical Sciences of Ribeirão Preto, University of São Paulo, Ribeirão Preto, São Paulo, Brazil, \\ ${ }^{3}$ Pharmacist, External colaborator, Private Pharmacy
}

\begin{abstract}
Tretinoin is used in the management of acne and it is part of a gold standard treatment for photoaging. It has also been reported as an agent for superficial chemical peeling in highly concentrated formulations with few considerations about skin penetration. The aim of this study was to evaluate the influence of drug concentration and vehicles currently used on skin penetration of tretinoin. In vitro permeation tests were carried out using Franz diffusion cells fitted with porcine ear skin and $10 \%$ aqueous methanol in the receptor compartment. Formulations studied, cream or hydroalcoholic dispersion, containing $0.25 \%, 1 \%$ and $5 \%$ of tretinoin were placed in the donor compartment for six hours. Tretinoin concentration in skin layers was measured by high performance liquid chromatography. The largest amount of tretinoin from both vehicles was detected in stratum corneum with significant differences among the three concentrations. The hydroalcoholic dispersion was the best vehicle. Significant amounts of tretinoin were found even in deep layers of epidermis. The formulation with $0.25 \%$ tretinoin showed better results when considered the amount of tretinoin on skin in terms of percentage. Finally, skin penetration of tretinoin was influenced by vehicle and concentration of this drug used in formulation.
\end{abstract}

Uniterms: Tretinoin/skin penetration/in vitro study. Chemical peeling. Topical formulations/analysis.

A tretinoína é usada no tratamento de acne e é considerada como padrão de ouro para o tratamento do fotoenvelhecimento. Em altas concentrações, é relatada como um agente para peeling químico superficial, com poucas considerações sobre a penetração na pele. O objetivo deste estudo foi avaliar a influência da concentração do fármaco e os veículos comumente usados na penetração cutânea da tretinoína. Testes in vitro de penetração foram realizados com células de difusão de Franz equipados com pele da orelha de porco e $10 \%$ de solução aquosa de metanol no compartimento receptor. As formulações estudadas, creme ou dispersão hidroalcoólica, contendo $0,25 \%, 1 \%$ e $5 \%$ de tretinoína foram colocadas no compartimento doador, durante seis horas. A concentração da tretinoína foi medida por cromatografia líquida de alta eficiência. A maior quantidade de tretinoína foi detectada no estrato córneo com diferenças significativas entre as três concentrações. A dispersão hidroalcoólica foi o melhor veículo. Quantidades significativas de tretinoína foram encontradas nas camadas profundas da epiderme. A formulação com $0,25 \%$ de tretinoína mostrou melhores resultados em termos de porcentagem penetrada na pele. Por fim, a penetração de tretinoína na pele foi influenciada pelo veículo e pela concentração desta utilizada na formulação.

Unitermos: Tretinoína/penetração na pele/estudo in vitro. Peeling químico. Formulações tópicas/análise.

*Correspondence: Patricia Maria Berardo Gonçalves Maia Campos. Faculdade de Ciências Farmacêuticas de Ribeirão Preto, University of São Paulo. Avenida do Café, s/nº, 14040-903 - Ribeirão Preto - SP, Brasil. E-mail: pmcampos@usp.br 


\section{INTRODUCTION}

Tretinoin (TRE) or all-trans-retinoic acid (RA) is indicated for treatment of acne vulgaris, melasma, photoaging, follicular keratosis, striae and disorders of keratinization (Thiboutot, Gollmick, 2009). It is well known that retinoids act by binding to specific nuclear receptors, interfering in gene expression and affecting cellular proliferation and differentiation, sebum production, inflammation, immunological reactions and possibly in non-melanoma skin cancer prevention (Stratigos, Katsambas, 2005).

The nuclear retinoic acid receptor family (RARs e RXR) is activated by TRE. By interaction with RARs and RXR, TRE executes its effect by one or more mechanism(s): a) epidermal thickening due to initiation of epidermal proliferation; b) compaction of the stratum corneum; and c) biosynthesis and deposition of the glycosoaminoglycans and collagen (Raza et al., 2013).

Since the 80 's it has been demonstrated that continuous use of $0.025 \%, 0.05 \%$ or $0.1 \%$ TRE cream may repair clinical and histological signs of photoaging (Kligman, Duo, Kligman, 1984; Samuel et al., 2005; Ting, $2010)$. Higher drug concentrations ( $1 \%$ to $5 \%$ ) have been proposed as peeling agents in adjuvant treatments of slight and moderate photoaging, melasma and poikiloderma (Cucé et al., 2001; Khunger, Sarkar, Jain, 2004; Landau, 2008).

Chemical peelings consist of topical applications of caustic substances, which result in the loss and regeneration of superficial skin layers. Classical agents are: Jessner' solution, 70\% glycolic acid, 30\% salicylic acid and 10 to $35 \%$ tricloroacetic acid. Their use is indicated as adjuvant treatments for various dermatosis such as photoaging, acne, melasma, hyperpigmentations, scars among others (Roy, 2005). Sequential superficial chemical peelings may result in epidermis and papillary dermis reorganization (Imayama, Ueda, Isoda, 2000).

The application of high concentration TRE formulations at the beginning of treatment in self usage or in sequential superficial peelings could be useful to produce retinoid benefits in a shorter period of time. However, to obtain these benefits it is necessary that topical drugs penetrate through follicular and sweat openings, intercellular spaces, stratum corneum (SC) or keratinocytes (Wester, Maibach, 1994). Human skin is a highly effective barrier against penetration of chemical and other agents. Thus, skin penetration depends on SC thickness, integrity and lipid composition, number of follicular openings, drug concentration and formulation vehicle (Manconi et al., 2006; Contrera et al., 2005).

For this, various in vivo and in vitro methods have been proposed to evaluate skin penetration. Among these methods, we used the Franz cell method to shed some light on the possible mechanism of skin penetration by formulations under study.

Considering that skin penetration could influence the cutaneous effects of the tretinoin-based formulations, the aim of this study was to evaluate the skin penetration of TRE vehiculated in two vehicles currently used as in three different concentrations.

\section{MATERIAL AND METHODS}

\section{Material}

All material used in this study were obtained from Galena (São Paulo, Brazil). Different TRE concentrations $(0.25 \%, 1 \%$, and $5 \%)$ were used as cream (stable emulsion composed of cetearyl alcohol, sodium cetearyl sulfate, decyl oleate, phenoxyethanol, parabens, glycerin and distilled water) and as hydroalcoholic dispersion (equal parts of distilled water and ethanol). The experimental skin was porcine ear and analytical grade $10 \%$ methanol was used in the receptor compartment of the Franz diffusion cell (HPLC grade, Sigma-Aldrich, Germany).

\section{Penetration tests in vitro}

The receptor chamber of a Franz diffusion cell (Microette-Hanson Research, Chatsworth, CA, USA) was composed of six individual cells with porcine skin placed with dermis facing the methanol solution and $400 \mathrm{mg}$ of TRE formulations were placed in the donor chamber. The entire system was kept at $37 \pm 0.5^{\circ} \mathrm{C}$ in a thermostated bath during the permeation test ( 6 hours). Removed skin samples were rinsed to eliminate excess formulation and fixed. The SC was separated from epidermis and dermis by 14 repeated tape strippings using adhesive strips (Scotch Book Tape, n.845; 3M, St. Paul, MN, USA). TRE in stripings and skin layers was extracted by $10 \%$ aqueous methanol and quantified by Bonhomme (1990) method in High Performance Liquid Chromatography (HPLC) as were the contents of the receptor chambers (SPD-10A, equipped with VIS-UV detector operating at $343 \mathrm{~nm}$ ). TRE concentrations in SC and epidermis + dermis represent topical delivery, whereas transdermal delivery is defined by the amounts detected in the receptor chamber.

\section{Validation of the analytical method}

A dose equivalent to $5 \mathrm{mg}$ of TRE was dissolved in $5 \mathrm{~mL}$ of methanol $(1 \mathrm{mg} / \mathrm{mL})$. Aliquots were diluted in 
methanol to obtain the following concentrations: 5,10 , $20,25,50,60,75$ and $100 \mu \mathrm{g} / \mathrm{mL}$, which were analyzed in triplicate by HPLC-UV (Bonhomme, 1990); results were inserted into a graph with three curves. The medium curve was in accordance to Brazilian Regulatory Agency (Agência Nacional de Vigilância Sanitária, ANVISA, Brazil). Linearity was evaluated through the coefficient of variation of replicate points and the coefficient of linear correlation $\left(\mathrm{r}^{2}\right)$. Accuracy was assessed by the coefficient of variation in determinations at each point of the calibration curve in triplicate during three consecutive days (inter-day) as well as in three points 10 times in one day (intra-day). Precision was calculated by variation between expected and observed concentrations at each point of the calibration curve when solutions were analyzed in triplicate for three consecutive days (inter-day) and 10 times in one day (intra-day).

\section{Statistical analysis}

Data analysis was carried out with the software OriginPro 7.0 (OriginLab Corporation, USA). Results are expressed by means \pm standard deviation. Multiple comparisons of means (Tukey test) were used to substantiate statistical differences among each sample and skin layer (stratum corneum and epidermis + dermis). Significance was tested at the 0.01 level of probability (p). The results for different vehicles were analyzed separately, i.e., one ANOVA for each of the two used considering three TRE concentrations $(0.25,1$ and $5 \%)$. Data variation analysis was performed in a completely randomized design, considering two experiments analyzed separately (two vehicles), composed of three treatments $(0.25,1$ and $5 \%$ TRE concentrations in the sample) $x 4$ replications per treatment $\mathrm{x} 2$ skin layer.

\section{RESULTS}

In the present experimental study, the skin penetration of six different formulations was tested. The in vitro topical and transdermal drug delivery was evaluated by the Franz diffusion cell test, a standard method for these procedures (Manconi et al., 2006). TRE amounts in skin layers and receptor chamber were quantified by HPLC, which was used under strict conditions to separate all-trans from 13-cis retinoic acid and other impurities as it had already been recommended (Manconi et al., 2006). Separation of trans isomer was satisfactory but over the time a slight degradation of TRE produced another compound, which was not identified.

The linear correlation coefficient determined in the TRE standard curve analysis by HPLC-UV was 0.998 which complied with limits established by ANVISA, Brazil, i.e., $\geq 0.99^{32}$. Accuracy and precision values showed coefficients of variation $\leq 4 \%$.

The greatest amounts of TRE were retained in SC regardless of the concentration in cream formulations. However, it was significantly higher when the $5 \%$ concentration was used $(p<0.01)$. The average amounts of TRE delivered into epidermis + dermis was not significantly different for $0.25 \%, 1 \%$ and $5 \%$ concentrations (Table I).

The amount of TRE, which permeated epidermis + dermis and reached the receptor compartment was lower than the method quantification limit.

The average amounts of TRE in hydroalcoholic dispersion retained in skin layers was significantly different $(\mathrm{p}<0.01)$ and much higher in SC than epidermis + dermis when comparing the three concentrations of drug used (Table II).

Comparing vehicles with the same concentrations of TRE the hydroalcoholic dispersion allowed higher penetration (Figure 1).

The cost-to-benefit ratio of each formulation was calculated in terms of percentage. The amount of tretinoin in each skin layer was divided by the total amount of tretinoin in each formulation. The results were expressed as a percentage of the total amount in the formulation. Among cream formulations, $0.25 \%$ showed the best relation in stratum corneum and epidermis + dermis (Figure 1). However, for hydroalcoholic dispersions, $0.25 \%$ TRE formulation showed only the best cost-tobenefit ratio in epidermis + dermis (Figure 1).

TABLE I - Tretinoin average concentrations retained in skin layers $\left(\mu \mathrm{g} / \mathrm{cm}^{2}\right)$ for the three cream formulations

\begin{tabular}{ccc}
\hline $\begin{array}{c}\text { Tretinoin concentration in cream } \\
\text { formulations }(\%)\end{array}$ & $\begin{array}{c}\text { Tretinoin retained in the stratum } \\
\text { corneum }\left(\boldsymbol{\mu g} / \mathbf{c m}^{2}\right)\end{array}$ & $\begin{array}{c}\text { Tretinoin retained in the epidermis }+ \\
\text { dermis }\left(\boldsymbol{\mu g} / \mathbf{c m}^{2}\right)\end{array}$ \\
\hline 0.25 & $17.37 \pm 3.79 \mathrm{~B}$ & $8.42 \pm 1.28 \mathrm{~A}$ \\
1 & $16.39 \pm 6.74 \mathrm{~B}$ & $7.66 \pm 3.97 \mathrm{~A}$ \\
5 & $53.96 \pm 9.37 \mathrm{~A}$ & $14.26 \pm 4.93 \mathrm{~A}$ \\
\hline
\end{tabular}

*Means followed by the same letter are not statiscally different $(\mathrm{p}<0.01)$. 
TABLE II - Tretinoin average concentrations retained in skin layers $\left(\mu \mathrm{g} / \mathrm{cm}^{2}\right)$ for the three hydroalcoholic formulations

\begin{tabular}{ccc}
\hline $\begin{array}{c}\text { Tretinoin concentration in } \\
\text { hydroalcoholic formulations }(\%)\end{array}$ & $\begin{array}{c}\text { Tretinoin retained in the stratum } \\
\text { corneum }\left(\boldsymbol{\mu g} / \mathbf{c m}^{\mathbf{2}}\right)\end{array}$ & $\begin{array}{c}\text { Tretinoin retained in the epidermis }+ \\
\mathbf{d e r m i s}\left(\boldsymbol{\mu g} / \mathbf{c m}^{2}\right)\end{array}$ \\
\hline 0.25 & $76.26 \pm 19.14 \mathrm{C}$ & $8.43 \pm 2.39 \mathrm{C}$ \\
1 & $276.24 \pm 67.87 \mathrm{~B}$ & $13.57 \pm 5.09 \mathrm{~B}$ \\
5 & $2074 \pm 651.13 \mathrm{~A}$ & $119.83 \pm 26.06 \mathrm{~A}$ \\
\hline
\end{tabular}

*Means followed by the same letter are not statiscally different $(\mathrm{p}<0.01)$.

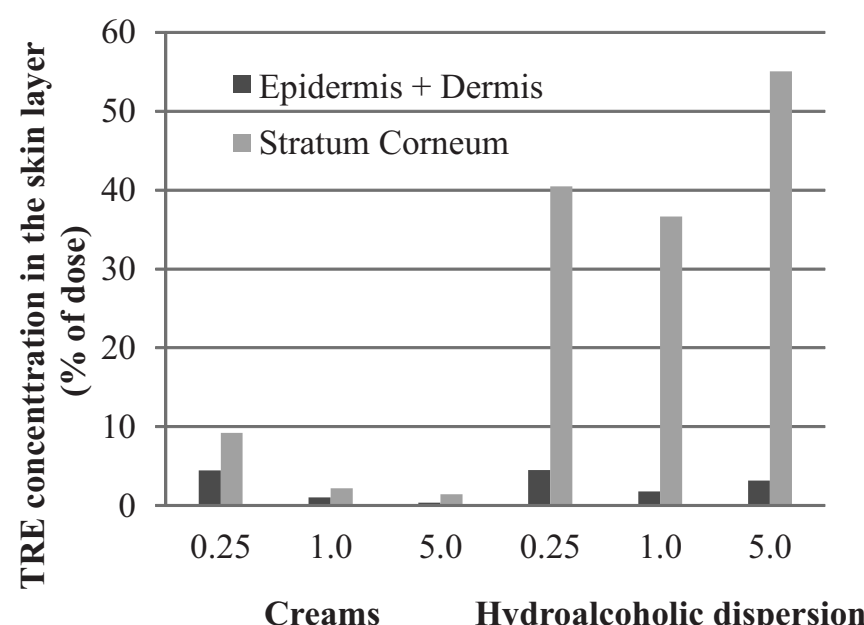

TRE concentration in each vehicle $(\%)$

FIGURE 1 - Percentages of TRE in skin layers delivered from three concentrations of the drug in cream and hydroalcoholic dispersion formulations.

\section{DISCUSSION}

The first proposal about the use of highly concentrated TRE as an agent for superficial peeling was reported by a Brazilian group in 2001 (Cucé et al., 2001). The authors sequencially used 1, 2, 3, 4 and 5\% TRE concentrations in a solution with equal parts of ethanol and propilenoglycol. They suggested two applications per week, in five sessions and reported no discomfort other that the remaining solution should be washed out after 6 to 12 hours, at home. One year later, they recommended the use of 5\% TRE peeling, once a week, in three applications (Cucé, Bertino, 2002). At that time, a letter was sent to the journal questioning stability and the advantage of such a high concentration (Kligman, 2001).

Retinoids are the most effective comedolytic agents. They provide multiple benefits for acne treatment such as: normalizing desquamation of the follicular epithelium, preventing formation of new microcomedo and minimizing the formation of comedones and inflammatory lesions (Manela-Azulay, Bagatin, 2009).
However, they cause irritative dermatitis during the early phase of skin retinization, which may lead to discontinuation of treatment (Kang et al., 2005). Thus, considering that the tretinoin penetration on the skin could influence the efficacy of the tretinoin-based formulation, this study can contribute for the definition of the best TRE concentration and vehicle in order to obtain the best results and a rational use of this active ingredient, as well as, avoid undesirable effects.

The skin is the largest organ and, as our primary external barrier, it is on the forefront of the battle with external causes of damaging free radicals. The most significant damage by free radicals is to biomembranes and to DNA. It is thought that topical use of vitamins and antioxidants in cosmetics and skin care products can better protect and possibly correct the damage by neutralizing these free radicals. In addition, some vitamins may be beneficial to the skin because of other actions such as suppression of pigmentation and bruising, stimulation of collagen production, refinement of keratinization, or anti-inflammatory effects (Lupo, 2001). In this sense, the highest amount of TRE found in stratum corneum likely indicates the effectiveness of TRE just for exfoliation.

The influence of concentration and vehicle in retinol formulation stability and skin penetration has already been demonstrated in vitro (Gomes, Gaspar, Maia Campos, 2007; Bagatin et al., 2010). The search for an acceptable delivery system for all-trans retinoic acid with no risk of systemic absorption and side effects, using mice abdominal skin as an experimental model, demonstrated that the encapsulated form (multilamellar large vesicles) promoted retention on skin superficial layers and prolonged drug release (Gomes, Gaspar, Maia Campos, 2007).

Skin penetration of vitamin A (retinol) in two vehicles, self-nanoemulsifying system and classic gel cream, using Franz cells method was evaluated (Gianetti et al., 2012) The authors found that both formulations presented the same particle size and the gel cream classic formulation furnished better penetration in both stratum corneum and epidermis + dermis. 
Concerning to drug delivery, it is essential that the drug pass the skin barrier (stratum corneum) to reach the living cells (Mak et al., 2011). Thus, we can speculate that the low percentage of tretinoin that penetrated the epidermis and the risk of side effects of high TRE concentration suggest limited advantage of its use as agent for chemical peeling, except if the desirable result is just an exfoliation.

To be effective in acne and photoaging treatments, TRE must cross the SC and reach deeper layers where it may reduce sebum production and follicular hyperkeratinization as well as increase collagen synthesis by binding to specific receptors (Draelos, Ertel, Berge, 2006; Bellemère, 2009).

The tested formulations may be considered effective since the percentage of TRE deposited in skin layers was more than $18 \%$ in some samples $(5 \%$ hydroalcoholic dispersion). A novel class of lipossomes to promote dermal delivery of TRE was developed and authors observed, as the highest percentage of penetration in porcine skin after 8 hours, no more than 12\% (Manconi et al., 2011).

A recent study about TRE skin penetration demonstrated that an ethanol solution presented the best drug penetration profile. After 6 hours of application, around $50 \%$ of TRE had permeated mice skin (Raza et al., 2013).

The rapid retinization of photoaged facial skin by daily topical application of $0.25 \%$ TRE had already been suggested (Kligman, Draelos, 2004).

Under experimental conditions, $0.25 \%$ TRE cream formulation showed high cost-to-benefit ratio mainly when compared to the cream formulations with four (1\%) and, twenty $(5 \%)$ times of this active ingredient. Additionally, cream vehicles could reduce the irritation caused by TRE. Thus, a rapid retinization of skin without pronounced side effects could be achieved using a more rational TRE concentration and a suitable vehicle.

Finally, the present study highlights the importance of vehicle and TRE concentration on skin penetration to achieve desire effects and avoid common problems like skin irritation, erythema and desquamation.

\section{CONFLICT OF INTEREST}

The authors declare that there is no financial or personal relationship that can be understood as representing a potential conflict of interest.

\section{REFERENCES}

ANVISA. Agência Nacional de Vigilância Sanitária (Portuguese). Available at: http://portal.anvisa.gov.br. Accessed on: 22 June 2013.

BAGATIN, E.; AGUIAR JR, N.R.; WAGEMAKER, T.A.L.; BONTEMPO, E.M.B.G.; MAIA CAMPOS, P.M.B.G. Penetração cutânea da tretinoína em três concentrações como agente para peeling químico superficial. In: CONGRESSO DA SOCIEDADE BRASILEIRA DE DERMATOLOGIA, 65., 2010. Posters. Rio de Janeiro: SBD, 2010. E-Pôster PI, 540 - Cat. Investigação.

BELLEMÈRE, G. Antiaging action of retinol: from molecular to clinical. Skin Pharmacol. Phys., v.22, p.200-209, 2009.

BONHOMME, L. HPLC determination of the stability of retinoic acid in gel formulation. Int. J. Pharm., v.65, p.910, 1990 .

CONTRERAS, M.J.F.; SORIANO, M.M.J.; DIÉGUEZ, A.R. In vitro percutaneous absorption of all-trans retinoic acid applied in free form or encapsulated in stratum corneum lipid liposomes. Int. J. Pharm., v.297, p.134-45, 2005.

CUCÉ, L.C.; BERTINO, M. Re: Regarding tretinoin peeling. Dermatol. Surg., v.28, p.1097, 2002.

CUCÉ, L.C.; BERTINO, M.C.M.; SCATTONE, L.; BIRKENHAUER, M.C. Tretinoin peeling. Dermatol. Surg., v.27, p.12-14, 2001.

DRAELOS, Z.D.; ERTEL, K.D.; BERGE, C.A. Facilitating facial retinization through barrier improvement. Cutis, v.78, p.275-81, 2006.

GIANETTI, M.D.; WAGEMAKER, T.A.L.; SEIXAS, V.; MAIA CAMPOS, P.M.B.G. The use of nanotechnology in cosmetic formulations: the influence of vehicle in the vitamin A skin penetration. Current Nanosci., v.8, p.52634, 2012.

GOMES, M.L.C.; GASPAR, L.R.; MAIA CAMPOS, P.M.B.G. Influence of different concentrations of retinoids in dermocosmetic formulations in their beneficial and/or collateral effects in hairless mice skin. In: INTERNATIONAL CONGRESS OF PHARMACEUTICAL SCIENCES, 6., Ribeirão Preto, 2007. 
IMAYAMA, S.; UEDA, S.; ISODA, M. Histologic changes in the skin of hairless mice following peeling with salicylic acid. Arch. Dermatol., v.136, p.1390-5, 2000.

KANG, S.; BERGFELD, W.; GOTTLIEB, A.B.; HICKMAN, J.; HOMENIUK, J.; KEMPERS, S.; LEBWOHL, M.; LOWE, N.; MCMICHAEL, A.; MILBAUER, J.; PHILLIPS, T.; POWERS, J.; RODRIGUEZ, D.; SAVIN, R.; SHAVIN, J.; SHERER, D.; SILVIS, N.; WEINSTEIN, R.; WEISS, J.; HAMMEMBERG, C.; FISHER, G.J.; NIGHLAND, M.; GROSSMAN, R.; NYIRADY, J. Long-term efficacy and safety of tretinoin emollient cream $0.05 \%$ in the treatment of photodamaged facial skin: a two-year, randomized, placebo-controlled trial. Am. J. Clin. Dermatol., v.6, n. 4, p.245-53, 2005.

KHUNGER, N.; SARKAR, R.; JAIN, R.K. Tretinoin peels versus glycolic acid peels in the treatment of melasma in dark-skinned patients. Dermatol. Surg., v.30, p.756-60, 2004

KLIGMAN, D.E. Regarding tretinoin peeling. Dermatol. Surg., v.27, p.608, 2001 .

KLIGMAN, D.E.; DRAELOS, Z.D. High-strenght tretinoin for rapid retinization of photoaged facial skin. Dermatol. Surg., v.30, p.864-866, 2004.

KLIGMAN, L.H.; DUO, C.H.; KLIGMAN, A.M. Topical retinoic acid enhances the repair of ultraviolet-damaged dermal connective tissue. Connect Tissue Res., v.12, p.139150,1984

LANDAU, M. Chemical peels. Clin. Dermatol., v.26, p.200208, 2008.

LUPO, M.P. Antioxidants and vitamins in cosmetics. Clin. Dermatol., v.19, p.467-473, 2001.

MAK, W.C.; RICHTER, H.; PATZELT, A.; STERRY, W.; LAI, K.K.; RENNEBERG, R.; LADEMANN, J. Drug delivery into the skin by degradable particles. Eur. J. Pharm. Biopharm., v.79, p.23-27, 2011.

MANCONI, M.; SINICO, C.; CADDEO, C.; VILA, A.O.; VALENTI, D.; FADDA, A.M. Penetration enhancer containing vesicles as carriers for dermal delivery of tretinoin. Int. J. Pharma., v.412, p.37-46, 2011.
MANCONI, M.; SINICO, C.; VALENTI, D.; LAI, F.; FADDA, A.M. Niosomes as carriers for tretinoin. III. A study into the in vitro cutaneous delivery of vesicle-incorporated tretinoin. Int. J. Pharma., v.311, p.11-19, 2006.

MANELA-AZULAY, M.; BAGATIN, E. Cosmeceuticals vitamins. Clin. Dermatol., v.27, p.469-474, 2009.

RAZA, K.; SINGH, B.; LOHAN, S.; SHARMA, G.; NEGI, P.; YACHHA, Y.; KATARE, O.P. Nano-lipoidal carriers of tretinoin with enhanced percutaneous absorption, photostability, biocompatibility and anti-psoriatic activity. Int. J. Pharm., v.456, p.65-72, 2013.

ROY, D. Ablative facial resurfacing. Dermatol. Clin., v.23, p.549-559, 2005.

SAMUEL, M.; BROOKE, R.C.; HOLLIS, S.; GRIFFITHS, C.E. Interventions for photodamaged skin. Cochrane Db. Syst. Rev., v.1, CD001782, 2005.

STRATIGOS, A.J.; KATSAMBAS, A.D. The role of topical retinoids in the treatment of photoaging. Drugs, v.65, p.1061-1072, 2005.

THIBOUTOT, D.; GOLLNICK, H. New insights into management of acne: an update from the Global Alliance to improve outcomes in acne group. J. Am. Acad. Dermatol., v.60, p.S1-S50, 2009.

TING W. Tretinoin for the treatment of photodamaged skin. Cutis, v. 86, p.47-52, 2010.

WESTER, R.C.; MAIBACH, H.I. Percutaneous absorption and cosmetics. In: BARAN, R.; MAIBACH, H.I. (Eds.) Cosmetic Dermatology. Baltimore: Martin Dunitz, 1994. p.55-76.

Recevied for publication on $28^{\text {th }}$ January 2014 Accepted for publication on $24^{\text {th }}$ September 2014 